\title{
HILBERT-TYPE INEQUALITIES AND RELATED OPERATORS WITH HOMOGENEOUS KERNEL OF DEGREE 0
}

\author{
YANG BICHENG AND MARIO KRNIĆ
}

\begin{abstract}
In this paper we provide an unified approach to the Hilbert-type inequalities with homogeneous kernel of degree 0 and certain weight functions. As an application, we define the related Hilbert-type operators and analyze their norms. In the case of conjugate exponents, we obtain the best possible constants involved in the right-hand sides of derived inequalities, and norms of the Hilbert-type operators as well. Finally, we consider some special choices of homogeneous kernels and parameters.
\end{abstract}

Mathematics subject classification (2010): 47A07, 26D15.

Keywords and phrases: Hilbert-type inequality, Hardy-Hilbert type inequality, Hilbert-type operator, homogeneous kernel, weight function, norm.

\section{REFERENCES}

[1] A. BÉNYI AND C. D. OH, Best constants for certain multilinear integral operators, Journ. Ineq. Appl, Article ID 28582 (2006), 1-12.

[2] Y. BICHENG, On extension of Hilbert's integral inequality with some parameters, The Austral. Journ. of Math. Anal. and Appl., 1, 1 (2004), 1-8.

[3] Y. Bicheng, I. Brnetić, M. Krnić, and J. PeČarić, Generalization of Hilbert and HardyHilbert integral inequalities, Math. Inequal. Appl., 8, 2 (2005), 259-272.

[4] Y. Bicheng, On the norm of an integral operator and applications, Journ. Math. Anal. Appl., 321 (2006), 182-192.

[5] Y. BICHENG, A Hilbert-type integral inequality, Journ. Zheijang Univ. (Science Edition), 24, 2 (2007), $121-124$.

[6] Y. BICHENG, A relation to Hilbert's integral inequality and some basic Hilbert-type inequalities, Journ. of Ineq. in Pure and Appl. Math, 9, 2 (2008), 1-8.

[7] Y. Bicheng, The norm of operator and Hilbert-type inequalities, Science Press, Beijing, 2009.

[8] F. F. Bons ALL, Inequalities with non-conjugate parameters, Quart. J. Math. Oxford Ser., 2, 2 (1951), $135-150$.

[9] A. ČIŽMEŠIJA, M. KRnIĆ, AND J. PEČARIĆ, General Hilbert-type inequalities with non-conjugate exponents, Math. Inequal. Appl., 11, 2 (2008), 237-269.

[10] G. H. HARDY, Note on a theorem of Hilbert concerning series of positive term, Proc. of London Math. Soc., 23, 2 (1925), Records of Proc. xlv-xlvi.

[11] G. H. Hardy, J. E. LitTlewood, ANd G. Pólya, Inequalities, $2^{\text {nd }}$ edition, Cambridge University Press, Cambridge, 1967.

[12] M. KRniĆ AND J. PeČARIĆ, General Hilbert's and Hardy's inequalities, Math. Inequal. Appl., 8, 1 (2005), 29-51.

[13] M. Krnić, G. Mingzhe, J. PeČArić, And G. Xuemei, On the best constant in Hilbert's inequality, Math. Inequal. Appl., 8, 2 (2005), 317-329.

[14] M. Krnić, J. PeČArić, And P. Vuković, On some higher-dimensional Hilbert's and HardyHilbert's integral inequalities with parameters, Math. Inequal. Appl., 11, 4 (2008), 701-716.

[15] M. KRnić, Hilbert inequality and Gaussian hypergeometric functions, Journ. Math. Ineq. (to appear).

[16] J. KUANG, Introduction to real analysis, Hunan Education Press, Chansha, 1996. 
[17] V. Levin, On the two-parameter extension and analogue of Hilbert's inequality, J. London Math. Soc., 11 (1936), 119-124.

[18] D. S. Mitrinović, J. E. PEČARIĆ, AND A. M. FinK, Classical and new inequalities in analysis, Kluwer Academic Publishers, Dordrecht/Boston/London, 1993. 